NBER WORKING PAPER SERIES

A GENERAL EQUILIBRIUM SIMULATION STUDY

OF SUBSIDIES TO MUNICIPAL EXPENDITURES

Roger H. Gordon

Joel Slemrod

Working Paper No. 1080

NATIONAL BUREAU OF ECONOMIC RESEARCH 1050 Massachusetts Avenue

Cambridge MA 02138

February 1983

The research reported here is part of the NBER's research program in Taxation. Any opinions expressed are those of the authors and not those of the National Bureau of Economic Research. 


\title{
A General Equilibrium Simulation Study of Subsidies to Municipal Expenditures
}

\begin{abstract}
In the United States, local government expenditures are heavily subsidized through a variety of sources. This paper explores theoretically and then simulates empirically the effects of eliminating either of two federal subsidies encouraging local government expenditures: (1) income tax deductibility of local tax payments, and (2) the tax exempt status of interest on municipal bonds.

We find that eliminating the deductibility of local taxes raises the utility of all income groups, and of home owners as well as of renters. Making interest on municipal bonds taxable, however, substantially hurts the very rich, who lose a tax shelter, and may hurt the very poor, who pay more for municipal services. While most people gain, the net gain is very small.
\end{abstract}

Roger H. Gordon

Bell Labs

600 Mountain Avenue

Murray Hill, New Jersey 07974

(201) 582-6472

Joel Slemrod

Department of Economics

University of Minnesota

1151 Business Administration Building

Minneapolis, Minnesota 55455

(612) 373-3607 


\title{
A General Equilibrium Simulation Study of Subsidies to Municipal Expenditures*
}

by

\author{
Roger H. Gordon
}

Bell Laboratories

and

\section{Joel Slemrod}

University of Minnesota

In the United States, local government expenditures are heavily subsidized through a variety of sources. Most obviously, the tax law allows local tax payments to be deducted from taxable income, and makes interest paid on municipal bonds tax exempt. In addition, commercial and industrial property owners, as well as landlords, may end up paying for a moderate fraction of any extra public services benefiting local residents.

The purpose of this paper is to explore theoretically and then to simulate empirically the effects of eliminating either of two federal subsidies encouraging local government expenditures: (1) income tax deductibility of local tax payments, and (2) the tax exempt status of interest on municipal bonds. We find that eliminating the deductibility of local taxes raises the utility of all income groups, and of home owners as well as of renters. Making interest on municipal bonds taxable, however, substantially hurts the very rich, who lose a tax shelter, and may hurt the very poor, who pay more for municipal services. While most people gain, the net gain is very small.

\section{Theoretical Discussion of the Effects of Federal Subsidies}

In analyzing the effects of subsidies encouraging local public services, we assume a Tiebout world, in which costless mobility of residents among a large number of communities leads to an equilibrium in which residents in each community agree on what public services they want and pay the marginal (and average) costs to the community.' If the community pays the market price for both capital and labor inputs to public services, and so pays the going wage rate $w$ for labor and the 
rental cost of capital equal to the real interest rate $r-\pi$ plus depreciation $d$, then the unit cost of public services, using the unit cost function, can be denoted by $c(w, r-\pi+d)$.

How does the existing tax law change this cost of local public services? ${ }^{2}$ To begin with, when a community needs funds to purchase capital equipment, it can issue tax exempt bonds, at a nominal rate $r_{m}$ which is less than that available to other capital users. In addition, if it were to raise the capital costs directly from its residents (equity finance), rather than issue municipal bonds (debt finance), then the foregone nominal rate of return to its residents is just $r(1-t)$, where $t$ is the marginal personal income tax rate paid by the (homogeneous) residents. By choosing the cheapest form of finance, the rental cost of capital to the community is reduced to $\min \left(r_{m}, r(1-t)\right)-\pi+d .^{3}$

If resident owners itemize deductions under the personal income tax, then they can also deduct any tax payments to the community. If $i=1$ when resident owners itemize, and zero otherwise, then the after tax unit cost of public services is reduced further to $(1-i t) c\left(w, \min \left(r_{m}, r(1-t)\right)-\pi+d\right)$. Tenants cannot deduct such taxes, even if they do itemize, while landlords, as collection agents for the community, also do not save any taxes as property taxes and rents go up, so this subsidy is restricted to owner occupiers.

There are more subsidies to local expenditures than those implicit in the federal income tax. For example, a number of state and federal grants programs lower the implicit price to the community of extra expenditures. One extreme example is the circuit breaker program in Wisconsin, where poorer individuals receive back from the state $80 \%$ of what they pay in extra property taxes. ${ }^{4}$

In addition, extra expenditures benefiting residents may in part be funded by extra taxes collected from commercial and industrial property, as well as from landlords. To a degree, each of these groups would receive in compensation extra services, or in the latter case extra rent reflecting the value of extra services. Fischel [2] and White [11], for example, describe assumptions under which, with costless mobility of firms, compensation in equilibrium will be complete. It is generally presumed, though, that these groups do face a distorting property tax, and the other side of this presumption is that residents face a subsidy to marginal expenditures. Let $z$ denote the percent of 
marginal expenditures paid for by these nonresidential groups, including state and federal governments. The cost of a marginal unit of services now becomes $(1-z)(1-i t) c\left(w, \min \left(r_{m}, r(1-t)\right)-\pi+d\right)$.

We find below that for reasonable parameter values this cost of local public services is very low relative to the unsubsidized cost $c(w, r-\pi+d)$, particularly for those in higher tax brackets. Communities therefore pay far less than the opportunity cost of the resources used when they choose to increase public expenditures. Facing such a low price, they will choose too high a level of services on efficiency grounds. The prime objective of this paper is to estimate the size of the presumed efficiency gains, and their distribution across income groups, from eliminating either the income tax deductibility of local taxes or the tax exempt status of interest on municipal bonds.

Calculating the efficiency and distributional effects of such tax changes is quite difficult, however. Listing a few of the problems that must be faced: (1) There may be efficiency reasons for subsidizing local public services. Nonresidents benefit to a degree from a community's local public expenditures, benefits which the community ignores when choosing expenditure levels. ${ }^{5}$ (2) In the presence of other savings-investment distortions, it is not clear what the opportunity cost of municipal capital is. The pre-tax rate of return to capital in other uses varies by sector, since the tax treatment of capital varies by sectors. Alternatively, if more is saved to pay for municipal capital, the opportunity cost is measured by the marginal time preference rate of $r(1-t)-\pi$, which varies by individual. More must be known about from where municipal capital is being drawn before the efficiency cost of the subsidies can be calculated. (3) Costs may arise from the distortions affecting the relative attractiveness of debt vs. tax finance of municipal capital expenditures. For example, when municipal bonds are risky, potential losses to municipal bondholders reflect offsetting potential gains to municipal taxpayers. Each side of the financial transaction bears risk, ${ }^{6}$ yet there need be no net social risk. These risk bearing costs arise as communities attempt to take advantage of the tax incentive favoring debt finance. ${ }^{7}$ (4) Making interest on municipal bonds taxable would lead to a sharp increase in the taxable income of the wealthy, with an associated rise in their marginal tax rates. This increase in marginal tax rates 
would further distort many of their decisions. (5) Different income groups may be affected very differently by these tax changes. Eliminating the deductibility of property taxes raises the taxes mainly of rich homeowners, while making interest on municipal bonds taxable raises the taxable income mainly of the wealthy and raises the cost of municipal services most sharply for those in the lowest tax brackets. This variation of impact across income groups is an important aspect of the problem. (6) Since tenants cannot deduct property taxes whereas homeowners can, deductibility of property taxes creates an artificial incentive to own rather than rent. Were property taxes nondeductible for homeowners-itemizers, this distortion affecting tenure choice is eliminated. (7) Municipal expenditures are not small relative to the size of the economy as a whole. (In 1981, state and local government purchases of goods and services amounted to $12.4 \%$ of GNP). Changes affecting this large a sector would have nonnegligible general equilibrium price effects.

Facing this variety of problems in measuring the efficiency and distributional effects of eliminating these federal subsidies to local government expenditures, we chose to construct a small general equilibrium model of the U.S. economy which focuses on these issues. We then used the model to simulate the effects of these tax changes.

\section{Structure of the General Equilibrium Simulation Model ${ }^{8}$}

In designing a general equilibrium model, we attempted to construct a simple model which still manages to capture the various complications just described. The model has two real factor inputs, capital $(K)$ and labor $(L)$, and three real outputs, local public services $(G)$, corporate output $(X)$, and housing, which is either owner occupied $(H)$ or rented $(N)$. Housing requires only capital input, while output in the other two sectors is produced using Cobb-Douglas production functions. Local capital is financed either by issuing municipal bonds or raising taxes, depending on which is more attractive. Corporate capital is financed at an exogenous debt-equity ratio.

We consider nine separate income groups, each of which is divided into two subgroups, owner occupiers and renters. Each group consumes housing services (whether owned or rented), local public services, other current consumption goods (produced in the corporate sector), and future 
consumption. Consumption of local public services is assumed to equal own expenditures plus a fixed fraction $g$ of everyone else's public service expenditures, to capture any externalities. Income funding these expenditures comes from labor income plus real income earned on financial assets, all net of income tax, but plus transfers back from the federal government.

Relative prices for the various consumption goods were defined as follows. The price of current consumption goods is the numeraire. Yearly costs per dollar of housing for owner occupiers are set equal to the after-tax real opportunity cost of funds $r(1-t)-\pi$ plus depreciation. Yearly costs for renters simply equal the market rental rate (net of implicit payments for local public services). The yearly cost of local public services, as defined above, was modified slightly by allowing $z$ to vary for labor vs. capital expenditures, to capture the fact that federal grants programs often subsidize each factor differently. Finally, the price of future consumption was defined to equal $(1+r(1-t)-\pi)^{-n}$, where $n$ was arbitrarily set equal to ten. ${ }^{9}$

In addition to choosing how to allocate his consumption expenditures, each individual must also divide his wealth among the available assets: taxable bonds $(B)$, corporate equity $(E)$, municipal bonds $(M)$, rental housing $(N)$, owner occupied housing $(H)$, and municipal capital $\left(K_{g}\right)$. Of these, $E, M, H$, and $N$ are all assumed to be risky investments. In addition, individuals bear risk if their community issues municipal bonds, risk equal and opposite to that born by purchasers of municipal bonds. ${ }^{10}$ Also, the central government is assumed to transfer its net revenue back to individuals in proportion to their labor income, e.g. through changing the Social Security payroll tax rate. Because government revenue is stochastic, due to taxes on stochastic income, so is the transfer received by each individual.

In making consumption and investment decisions, each individual maximizes a utility function composed of a Cobb-Douglas function of the expected consumption of each good minus a parameter times the variance of his net income. ${ }^{11}$ This utility function leads to simple consumption and asset demand functions. The individual makes choices subject to an income constraint and a wealth constraint, ${ }^{12}$ and is assumed to be unable to go short in $M$ or $N$. However, it is assumed that he can borrow without limit - the IRS constraint preventing borrowing to buy municipal bonds is 
assumed not to be binding.

What fraction of individuals choose to rent vs. own in each of the nine groups is determined endogenously. In the initial equilibrium, these fractions were taken from the data. A simple logit equation is used to forecast the change in the fraction owning in response to tax changes. ${ }^{13}$

Both the federal personal income tax and corporate income tax are modelled in detail. Personal taxable income equals labor income plus taxable interest income less property tax payments of owner itemizers, ${ }^{14}$ plus taxable income from equity and apartments. Taxable income from apartments equals rent minus property tax payments minus tax depreciation plus a fraction of inflationary capital gains. Taxable income from equity equals dividends received (which are set equal to a fixed fraction of the real return to equity) plus a fraction of capital gains. Tax payments, and the marginal tax rate, were then determined from taxable income using a continuous approximation to the 1977 tax table for a joint filing unit with two dependents and an average amount of deductions. Since the tax law is explicitly part of the model, marginal tax rates are endogenous in the simulations.

Tax payments under the corporate tax equal $46 \%$ of taxable income minus investment tax credits on replacement investment. Taxable corporate income equals the real return on corporate capital minus tax depreciation, property taxes, and interest payments.

The model is closed using the standard accounting identities that require that supply equals demand in each market. All prices, factor allocations, consumption patterns, and asset holdings are endogenous in the model. The model describes only the new long run equilibrium, however, and not the path of adjustment in response to any policy change. In particular, capital, due to its long run mobility, will not experience a capital gain or loss in response to a policy change in the simulations.

\section{Selection of Parameter Values ${ }^{15}$}

Many parameter values have to be chosen before the model can be simulated. Data for these parameters come from a variety of sources. In many cases, we use the same values as have been used in other similar simulation studies. For example, capital and labor endowments of each income 
group are taken from Slemrod [10], corporate depreciation rates come from Fullerton-Gordon [3], while the parameter in the corporate production function comes from Shoven [9]. Other data come directly from government publications, e.g. the population and the property tax payments of each income class from the Statistics of Income, the housing share in consumption expenditures from the Survey of Consumer Expenditures, and the capital share in local production expenses from the 1972 Census of Governments.

A few choices for parameters deserve more discussion. Data used to calculate the variance in the return on equity come from Ibbotson-Sinquefield [6]. The variance in the return on taxable bonds, drawn also from Ibbotson-Sinquefield [6], is used to approximate the variance in the return on municipal bonds. The data used to construct the variance in an index of housing prices come from the Construction Reports of the Department of Commerce. However, individuals cannot easily diversify in housing. We assume arbitrarily that the variance in the price of an individual house or apartment is ten times as large as that of the housing price index. However, the covariance between the returns on owner-occupied housing and on apartments is set equal to the variance in the housing price index. Other covariances are set equal to zero in order to simplify the model. ${ }^{16}$

The property tax rate on corporate capital was initially set equal to half the ratio of observed property tax payments by corporations, nationally, to the total assessed corporate property value. To a degree, corporations receive back extra services when property taxes go up, so the full ratio is partly a user fee, and only partly a distorting tax. Ladd [7] reports from her empirical work that communities act as if fifty to eighty percent of commercial and industrial property tax payments are available to fund expenditures benefiting residents. We report below on the sensitivity of our results to changes in this parameter. ${ }^{17}$

The size of the marginal subsidy to local government expenditures created by the many federal and state grants and rebates is difficult to calculate. Many grants are nonmatching, so do not affect the cost of extra expenditures, and some of the matching grants have ceilings. Also, much of the expenditures on matching grants goes for welfare benefits, expenditures which do not fit easily into our model of Tiebout communities. Rather than analyze in detail the hundreds of federal and state 
programs, we assume simply that the state subsidy rate at the margin is $10 \%$, and that the federal rate at the margin is $10 \%$ on capital expenditures (e.g. pollution control facilities) and $5 \%$ on labor expenditures. These figures are intended to be conservative.

A key parameter about which next to nothing is known is the size of the externalities, $g$, to nonresidents created by an increase in a community's public expenditures. Lacking alternatives, we try two extreme cases. In the first, the spillover is assumed to be negligible. In the second, the total value of the spillover per unit of local services is assumed to equal the total size of existing subsidies per unit of local services, from federal and state grants, federal tax subsidies, and subsidies arising from the tax on corporate property. Under this assumption, the total expenditures on subsidies are those appropriate for a correctly designed Pigovian subsidy, though the design of actual subsidies differs substantially from that of Pigovian subsidies.

\section{Simulation Results}

Our primary simulations examine the effects of eliminating either (1) the income tax deductibility for homeowners-itemizers of local taxes, or (2) the tax exempt status of interest on municipal bonds. In these first simulations, we assume that half of property taxes on corporations are distorting and that there are no spillovers in local public expenditures.

The top third of Table I describes a few characteristics of the equilibrium prior to either change. The first line reports the percent of the total population in each income group. The second line gives the percent in each group who own their housing. The third line reports the per capita labor income in thousands of 1977 dollars within each group. The next two lines report the effective rental price of local public capital faced by owners and renters in each group, expressed as a percent of the full price $(r-\pi+d)$ and denoted by $P_{K G}$. Note both the low values and the sharp variation across groups.

The middle section of Table I describes some of the effects of eliminating the income tax deductibility of local taxes. The immediate impact of this tax change is to raise the cost of local public services for homeowners (particularly rich homeowners), as seen by comparing lines 4 and 6 
in Table I. This leads to a $13.6 \%$ drop in total output of public services $(G)$, shifting resources into more productive uses. Corporate output rises by $1.5 \% .^{18}$ Since only owners lose the tax deduction, the incentive to own drops and more people rent, as seen by comparing lines 2 and 7 in the table. As a result, while $N$ increases by $8.3 \%, H$ drops by $1.6 \%$. This shift from untaxed housing into taxed apartments is also an efficiency gain.

Within the model, the extra tax revenues are returned in a lump sum fashion in proportion to labor income, ${ }^{19}$ so any potential efficiency gains due to reducing other distorting tax rates are not captured. In spite of this, all groups are found to benefit from the policy change, even the rich owners who pay the most in extra income taxes. Lines $8 \mathrm{a}$ and $8 \mathrm{~b}$ in the table report for each group the percent increase in current consumption equivalent to the actual increase in utility. ${ }^{20}$ Renters are seen to gain relative to owners, as would be expected. On net there is a moderate efficiency gain the total equivalent increase in current consumption, summed across groups, is $0.94 \%$ of initial total current consumption. ${ }^{21}$ The efficiency gains from shifting factors out of producing the subsidized $G$ and the untaxed $H$ into other activities is substantial, and remarkably evenly spread across groups, at least given the assumed mechanism for returning government revenue.

In the second simulation, interest on municipal bonds is made taxable. The first immediate effect of this change is to raise the cost of municipal capital to the less rich groups, who previously faced the smallest subsidy. There is now a sharp tax disadvantage to financing municipal capital with debt - the deductibility of expenditures is not affected by the type of finance, while taxable income is generated only if debt finance is used. As a result, all groups now use solely tax finance of local capital - the municipal bond market disappears.

The second immediate effect is to eliminate a major tax shelter for the rich. As a result, marginal tax rates on the rich increase substantially, further distorting a number of their decisions. ${ }^{22}$ Investments in all lightly taxed assets increase, particularly in apartments, driving down their rates of return. The cost of municipal capital to the rich also falls dramatically, as the increased tax rate both lowers the opportunity cost of funds and raises the value of the local tax deduction. Lines 9 and 10 in the table show both the increased cost of $K_{g}$ to the poor, and the decreased cost to the 
rich. On net, $G$ falls by only $2.5 \% .^{23}$

Effects of the tax change on tenure choice are mixed, as seen in the table. The drop in market rental rates aids renters and leads more of the less rich to rent, while the increased tax rates faced by the rich lead more of them to own. On net, apartments increase by $8.5 \%$, while owned housing decreases by $1.3 \%$.

Lines $12 \mathrm{a}$ and $12 \mathrm{~b}$ in the table represent for each group the percent change in consumption equivalent to the actual change in utility. We find that the rich lose heavily, since a tax shelter disappears for them, while the poorest also fare less well, facing higher costs for municipal services. On net, though, $78 \%$ of the population gains, and the total equivalent increase in current consumption is $0.13 \%$ of initial total current consumption.

Our other simulations tested the sensitivity of these results to changes in parameters. For example, if the property tax on corporations is entirely distorting, a more common assumption, rather than half distorting, then the efficiency gain from eliminating the property tax deduction almost doubles. In contrast, the efficiency gain from making municipal bond interest taxable is now only half as large. As before, efficiency gains and losses almost counterbalance, with the rich losing heavily relative to other groups.

In our final simulations, we assume that the level of externalities from local public expenditures is large enough to justify in principle the current expenditures implicitly subsidizing them. Now when the deductibility of property taxes is eliminated, the level of utility still rises for all except owners in group 2, but the efficiency gain is less than half as large as previously. Making municipal bonds taxable now has essentially no net effect on efficiency, though $75 \%$ of the population still gains. 


\section{TABLE I}

\section{SIMULATION RESULTS}

\begin{tabular}{|c|c|c|c|c|c|c|c|c|c|}
\hline \multirow[t]{2}{*}{ Variable } & \multicolumn{9}{|c|}{ Group } \\
\hline & 1 & 2 & 3 & 4 & 5 & 6 & 7 & 8 & 9 \\
\hline \multicolumn{10}{|c|}{ Initial Equilibrium } \\
\hline 1. \% of population & 45.1 & 20.5 & 17.7 & 9.5 & 4.2 & 2.1 & 0.8 & 0.15 & 0.04 \\
\hline 2. \% homeowners & 48.3 & 59.5 & 73.9 & 82.4 & 89.6 & 91.5 & 92.2 & 92.2 & 92.2 \\
\hline $\begin{array}{l}\text { 3. Per capita labor } \\
\text { income ( } \$ 1000 \text { 's) }\end{array}$ & 3.2 & 9.3 & 15.1 & 20.1 & 27.6 & 31.6 & 46.17 & 9.5 & 144.3 \\
\hline 4. $P_{K G}$ (owners) & 43.9 & 33.3 & 30.3 & 25.8 & 22.7 & 21.2 & 16.7 & 15.2 & 13.6 \\
\hline 5. $P_{K G}$ (renters) & 42.4 & 40.9 & 37.9 & 36.4 & 31.8 & 30.3 & 25.8 & 24.2 & 22.7 \\
\hline \multicolumn{10}{|c|}{ Local Taxes Not Deductible } \\
\hline 6. $P_{K G}$ (owners) & 42.2 & 39.2 & 37.7 & 34.6 & 33.1 & 31.6 & 27.1 & 25.6 & 24.1 \\
\hline 7. $\%$ homeowners & 48.3 & 55.0 & 70.8 & 80.2 & 88.2 & 90.3 & 91.2 & 91.7 & 91.7 \\
\hline \multicolumn{10}{|c|}{ 8. Equivalent $\%$ change in consumption } \\
\hline a. owners & 2.29 & 0.18 & 0.54 & 0.63 & 0.55 & 0.61 & 0.48 & 0.79 & 0.73 \\
\hline b. renters & 2.27 & 2.22 & 2.05 & 2.18 & 2.12 & 2.09 & 1.80 & 1.48 & 1.38 \\
\hline \multicolumn{10}{|c|}{ Municipal Bonds Taxable } \\
\hline 9. $P_{K G}$ (owners) & 60.9 & 37.1 & 32.7 & 28.2 & 22.3 & 20.8 & 14.9 & 8.9 & 7.4 \\
\hline 10. $P_{K G}$ (renters) & 60.9 & 44.6 & 40.1 & 37.1 & 31.2 & 29.7 & 22.3 & 14.9 & 11.9 \\
\hline 11. \% homeowners & 45.6 & 57.2 & 72.0 & 80.8 & 88.8 & 91.0 & 93.1 & 95.6 & 96.1 \\
\hline \multicolumn{10}{|c|}{ 12. Equivalent $\%$ change in consumption } \\
\hline a. owners & -0.57 & 0.35 & 0.54 & 0.55 & 0.22 & 0.00 & -2.27 & -5.58 & -6.60 \\
\hline b. renters & 0.57 & 1.30 & 1.14 & 1.09 & 0.59 & 0.10 & -2.95 & -6.29 & -7.09 \\
\hline
\end{tabular}

Note: $\boldsymbol{P}_{\boldsymbol{K} G}$ is the effective rental price of local public capital, expressed as a percent of the full price $(r-\pi+d)$. 


\section{FOOTNOTES}

* We would like to thank Robert Inman and Michelle White for help in locating data sources, and particularly Leonard Burman for able research assistance throughout the project. The views expressed are those of the authors and do not necessarily reflect those of Bell Laboratories or the Bell System.

1. For a formal development of the assumptions underlying this model, see McGuire [8] and Hamilton [5].

2. To simplify the discussion, we ignore uncertainty here and assume that individuals can borrow without limit, but cannot go short in municipal bonds. We allow for uncertainty in the simulation model, however.

3. Note that with certainty, the wealthy will arbitrage between tax exempt and taxable bonds until their marginal tax rate is driven down to the point where $r_{m}=r(1-t)$.

4. For further discussion on Wisconsin circuit breakers, see Bendick [1].

5. A community's decisions can create a number of other types of externalities, as discussed in Gordon [4].

6. This risk lessens the attractiveness to residents of using debt financed municipal capital.

7. In addition to risk bearing costs, real bankruptcy costs or other agency costs may also arise, as they do as a result of the tax distortion favoring debt finance by corporations.

8. This model draws heavily from the model developed by Slemrod [10].

9. The efficiency cost of any distortion to savings incentives will be an increasing function of $n$ in the model, since the price of future consumption fluctuates more when $n$ is larger.

10. We ignore any real bankruptcy costs or agency costs that may arise when municipal bonds are issued. 
11. One problem with this utility function is that demand for risky assets is invariant to wealth. To avoid this implication, we divided the parameter multiplying the variance of income by the wealth of the individual. Also, it should be noted that the model does not fully capture all sources of uncertainty. For example, all prices should in principle be stochastic.

12. Use of two constraints rather than one is needed since we do not have explicit lifetime decision making subject to lifetime income. We instead impose the assumption that current consumption is a function solely of current income, regardless of wealth or other factors.

13. The tenure choice was assumed to involve a trade-off between the monetary savings from owning vs. renting, as a percent of income, and any tastes to own vs. rent. The monetary savings were defined to be the difference between the market rental rate and the per unit cost of housing (including the cost of bearing risk) to owners, times the demand for housing, plus the gain from being able to deduct local property taxes, minus the loss from no longer using the standard deduction. Given the stochastic assumptions about tastes underlying the logit specification, we then express the logarithm of the odds of owning vs. renting as a linear function of these monetary savings divided by income. This equation was estimated using the data on the nine income groups constructed for use in the simulation model.

14. We assume that all owner occupiers itemize, so all deduct local taxes, in spite of the fact that many fewer people itemize than own housing. Our presumption was that most all owners itemize for a number of years after their initial purchase. Since during this period they face a cheaper price for local public services, they will shift public expenditures into this period, out of periods when they do not itemize.

15. The discussion in this section is by necessity brief. Further information may be obtained from the authors.

16. In no case did the correlation between the returns on two assets exceed 0.1 .

17. In all cases, however, we assume for simplicity that the average and the marginal subsidy rates, $z$, are equal. Mobility of firms in response to tax changes could in general cause the 
rates to differ.

18. This increase is encouraged by a drop of twenty basis points in the net property tax rate on corporate capital, due to the drop in local tax collections.

19. Labor supply is exogenous in the model. This formula for returning the revenue aids relatively the poor, who pay little or no taxes but receive transfers, and the very rich, whose labor income is much larger than their taxable income due to their borrowing heavily to buy lightly taxed assets.

20. These numbers equal the change in utility, divided by the initial marginal utility of other current consumption, then expressed as a percent of initial other current consumption.

21. The size of each group used to weight per capita changes is the average of the population of the group before and after the policy change.

22. No group was near the maximum marginal tax rate.

23. Capital-labor ratios in the local public sector also fall, since this tax change affects directly only the cost of capital. 


\section{REFERENCES}

[1] M. Bendick, Jr. "Designing Circuit Breaker Property Tax Relief" National Tax Journal. 27 (March, 1974), 19-28.

[2] W. A. Fishel, "Fiscal and Environmental Considerations in the Location of Firms in Suburban Communities." in Fiscal Zoning and Land Use Controls, edited by E. S. Mills and W. E. Oates. Lexington: Lexington Books, 1975.

[3] D. Fullerton and R. H. Gordon. "A Reexamination of Tax Distortions in General Equilibrium Models." in Simulation Methods in Tax Policy Analysis, edited by M. S. Feldstein. Chicago: University of Chicago Press, 1983.

[4] R. H. Gordon. "An Optimal Taxation Approach to Fiscal Federalism." Mimeo, 1982.

[5] B. W. Hamilton "Capitalization of Intrajurisdictional Differences in Local Tax Prices." American Economic Review. 66(1976), 743-53.

[6] R. G. Ibbotson and R. A. Sinquefield. Stocks, Bonds, Bills and Inflation: The Past and the Future. Charlottesville, Va.: The Financial Analysts Research Foundation, 1977.

[7] H. F. Ladd. "Local Education Expenditures, Fiscal Capacity, and the Composition of Property Tax Base." National Tax Journal. 28 (June, 1975), 145-58.

[8] M. McGuire. "Group Segregation and Optimal Jurisdictions." Journal of Political Economy. 82(1974), 112-32.

[9] J. B. Shoven. "Incidence and Efficiency Effects of Taxes on Income from Capital." Journal of Political Economy. 84 (1976), 1261-1283.

[10] J. Slemrod. "A General Equilibrium Model of Taxation with Endogenous Financial Behavior." in Simulation Methods in Tax Policy Analysis, edited by M. S. Feldstein. Chicago: University of Chicago Press, 1983.

[11] M. J. White. "Firm Location in a Zoned Metropolitan Area." in Fiscal Zoning and Land Use Controls, edited by E. S. Mills and W. E. Oates. Lexington: Lexington Books, 1975. 